\title{
FACTORS DETERMINING THE USE OF SEWAGE SLUDGE AS A SUBSTRATE FOR ENERGY RECOVERY
}

\author{
Karolina JĄDERKO-SKUBIS ${ }^{1 *}$, Krzysztof KURUS ${ }^{2}$ \\ ${ }^{1}$ Central Mining Institute; Katowice; kjaderko@gig.eu, ORCID: 0000-0002-7861-1173 \\ ${ }^{2}$ WSB University, Dąbrowa Górnicza; krzysztof.kurus@gmail.com, ORCID: 0000-0002-5336-6095 \\ * Correspondence author
}

Purpose: The aim of the article was to present the problems of converting sewage sludge into energy in relation to the strategies and legal regulations in force in Poland. This publication is an attempt to identify the factors determining the use of sewage sludge as substrates for energy recovery.

Design/methodology/approach: The scope of undertaken research included quantitative analysis of the generated sludge, qualitative analysis, in order to define the parameters constituting the possibility of its effective use in energetics, as well as identification and evaluation of key determinants influencing the choice of the method of sludge management.

Findings: Thermal treatment of sewage sludge is one of the strategic management directions chosen for this kind of waste. Based on the analyses and evaluation of the presented technological solutions in the field of research, it was indicated that the key factor limiting the general use of sewage sludge as a fuel is an economic issue, especially in relation to the cost of sludge preparation.

Originality/value: The implementation of increasingly restrictive requirements in the field of sludge management forces the sludge treatment plants to find new solutions in order to manage them efficiently. Due to the above, the paper presents the basic factors that determine the initiation of studies concerning the use of the energy potential of the generated sludge.

Keywords: sewage sludge, waste to energy, incineration, alternative fuels.

Category of the paper: Research paper, literature review.

\section{Introduction}

Due to the increasing amount of sewage sludge, generated as a result of changing lifestyles, as well as the increased percentage of inhabitants connected to the sewage network, water supply companies are facing an increased demand for their services. In addition to that, the prohibition of sewage sludge storage has significantly contributed to speeding up the works 
on solving the problem of implementing rational waste management systems, based on sludge treatment in municipal sewage treatment plants.

In recent years, it can be seen that sewage treatment plants are increasingly looking for alternative technologies for sludge management, in order to benefit from the potential of this type of waste and implement solutions that would bring some additional profit.

According to the data from Statistics Poland for 2018, 583 thousand tons of sewage sludge was produced in Poland, most of which was used for agricultural purposes. In spite of a growing interest in thermal waste processing technologies, a number of specific determinants still cause a barrier to entrepreneurs' interest in this area.

While many of the studies deal with isolated topics related to the use of sewage sludge as an alternative fuel source, there are still no attempts to develop a comprehensive approach to identify key determinants that decide on the effectiveness of such solution.

The fact that individual sewage sludge management technologies are widely used can be proven not only by economic factors, but also by environmental, technological, logistic and even social factors. Among those, the social factor, i.e. the acceptance associated with the proposed reuse of sludge, either for agricultural purposes or for energy processing, is especially important.

A number of economic and non-economic factors is also strongly regulated by legal aspects, which are the foundation of any change in the waste management method, including sewage sludge. Additionally, due to the amount of generated sludge and the increasing efficiency of sewage treatment plants, caused by the dynamic development of the water and sewage infrastructure, it seems obvious that it is necessary to expand the infrastructure for its rational management.

It should be noted, that municipal sewage sludge, which is a by-product of the sewage treatment process, according to the Regulation of the Minister of the Environment of December 9, 2014, on the catalogue of waste, has the code 190805 (stabilized municipal sewage sludge). This means that there is a hierarchy of waste management with the priority of prevention, followed by preparation for re-use, recycling and recovery (including, for example, energy recovery through fermentation and energy production from biomethane or through incineration). In this context, it seems crucial to make use of those physico-chemical properties of the waste that would optimally become the focus of treatment and management. Despite the recommended directions and strategies, the legal and financial aspects of the use of sludge from sewage treatment plants, as well as the specific conditions, determine the choice of a solution. In this publication, an attempt is made to identify the key factors determining the use of sludge as a substrate for energy generation. 


\section{Methods}

In order to achieve the main objective of this work, which was to identify the factors determining the use of sewage sludge as an alternative fuel, the research methodology included the following elements:

- quantitative analysis of generated sewage sludge streams on the basis of available statistical data, taking into account the methods of their management,

- qualitative analysis of sewage sludge, in order to define the parameters which determine the possibility of its effective use in energetics,

- analysis of legal and strategic documents determining the directions of sewage sludge management,

- analysis and evaluation of selected solutions used for energy use of sewage sludge,

- identification of key determinants influencing the selection of the method of sewage sludge treatment.

\section{Results}

\subsection{Quantitative and qualitative characteristics of sewage sludge generated in Poland}

As it was mentioned in 2018, according to the statistics, the amount of municipal sewage sludge generated in Poland was 583.1 thousand Mg. Taking into account the trends that were observed in the generation of municipal sewage sludge and the dynamic development of sewage and water supply networks, resulting in an increased amount of sludge, it is assumed that, in terms of dry matter, the amount of sludge will increase by about $2-3 \%$ each year (KPGO, 2016).

Data concerning the amount of municipal sewage sludge generated and managed in the years 2014-2018 are presented in the table below (Table 1).

It is worth noting, that storage of sludge on the territory of a sewage treatment plant has a significant share in the statistics of municipal sewage sludge management. This indicates the existence of barriers, probably legal or technical, which limited the proper management of municipal sewage sludge.

Municipal sewage sludge generated in the treatment plant in its original form cannot be treated as natural fertilizer (Bauman-Kaszubska and Sikorski, 2011), nor as a substrate for the production of alternative fuels. Only a properly selected sludge treatment process (processing and stabilization), resulting from the physical and chemical properties of the sludge, allows to prepare the sludge for its final management. 
Table 1.

Municipal sewage sludge generated during the year in [Mg]

\begin{tabular}{|c|c|c|c|c|c|}
\hline Description & $\mathbf{2 0 1 4}$ & $\mathbf{2 0 1 5}$ & $\mathbf{2 0 1 6}$ & $\mathbf{2 0 1 7}$ & $\mathbf{2 0 1 8}$ \\
\hline total & 555,982 & 568,017 & 568,329 & 584,454 & 583,070 \\
\hline used in agriculture & 107,222 & 107,536 & 116,028 & 108,520 & 118,333 \\
\hline $\begin{array}{c}\text { used for land reclamation, including land for } \\
\text { agricultural purposes }\end{array}$ & 21,961 & 19,167 & 20,075 & 19,695 & 17,410 \\
\hline $\begin{array}{c}\text { used for plants intended for the production of } \\
\text { compost }\end{array}$ & 46,330 & 47,103 & 31,817 & 25,889 & 25,196 \\
\hline thermally transformed & 84,237 & 79,274 & 101,144 & 106,158 & 111,544 \\
\hline stored together & 31,503 & 40,458 & 20,666 & 15,250 & 10,638 \\
\hline stored temporarily & 62,192 & 56,397 & 47,253 & 51,325 & 50,011 \\
\hline
\end{tabular}

Adapted from: Statistics Poland (stat.gov.pl) and Local Data Bank (bdl.stat.gov.pl)

In the context of energy use of waste, in this case sewage sludge, the basic parameter determining the possibility of its processing as a fuel source is its calorific value, which depends on the moisture and ash content and, in the case of sewage sludge, mainly on its chemical composition (the mass of organic compounds). In addition, the high degree of hydration of sewage sludge (up to 99\%) decreases its energy properties (Kuklis et al., 2014).

For comparison, Figure 1 presents the ranges of calorific values for conventional fuels: fossil (hard coal) and waste treated as alternative fuels (sewage sludge, municipal waste, biomass, coal shale and sludge, as well as solid shredded waste - an example of alternative fuel prepared through earlier processing and shredding of waste).

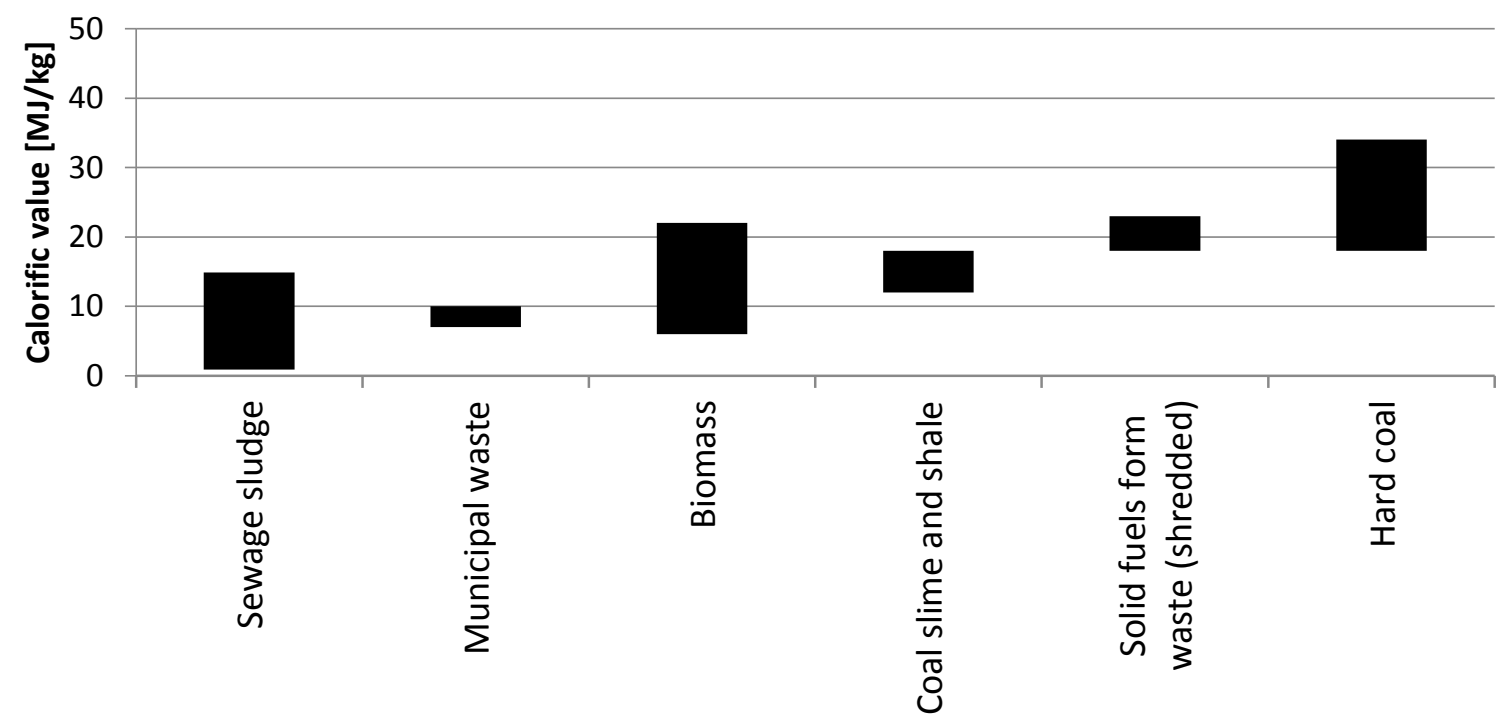

Figure 1. Range of calorific value of selected fuels and waste for alternative fuels. Adapted from: (Kuklis, I. et al., 2014; Sorek, A., 2012; Ostrojski, A., 2015)

As shown in the above figure, sewage sludge, compared to other waste and fuels, is characterized by a comparable calorific value, especially to municipal waste and biomass. Municipal sewage sludge is waste that can be used as an autonomous solid secondary fuel or component. In practice, to increase calorific value and energy attractiveness, dried sewage 
sludge can be used as a substrate for the production of formed fuels, mixing it with other highcalorific waste.

The requirements for alternative fuels include mainly three dimensions - calorific value, chlorine content and mercury content (Table 2). This is mainly related to the production of standardized Solid Recovered Fuel (SRF), which must meet the quality criteria set out in CEN/TC343 (EN15359) (Szpadt, 2012).

\section{Table 2.}

Solid Recovered Fuel classes

\begin{tabular}{|c|c|c|c|c|c|c|c|}
\hline $\begin{array}{c}\text { Classification } \\
\text { parameter }\end{array}$ & $\begin{array}{c}\text { Statistical } \\
\text { measurement }\end{array}$ & Unit & \multicolumn{5}{|c|}{ Class } \\
\cline { 4 - 7 } & & $\mathbf{1}$ & $\mathbf{2}$ & $\mathbf{3}$ & $\mathbf{4}$ & $\mathbf{5}$ \\
\hline $\begin{array}{c}\text { net calorific } \\
\text { value }(\mathrm{NCV})\end{array}$ & average & $\mathrm{MJ} / \mathrm{kg}$ & $\geq 25$ & $\geq 20$ & $\geq 15$ & $\geq 10$ & $\leq 3$ \\
\hline $\begin{array}{c}\text { chlorine } \\
\text { content }(\mathrm{Cl})\end{array}$ & average & $\% \mathrm{wt}$ & $\leq 0.2$ & $\leq 0.6$ & $\leq 1.0$ & $\leq 1.5$ & $\leq 3$ \\
\hline $\begin{array}{c}\text { mercury } \\
\text { content }(\mathrm{Hg})\end{array}$ & $\begin{array}{c}\text { median } \\
\text { percenth }\end{array}$ & $\mathrm{mg} / \mathrm{MJ}$ & $\leq 0.02$ & $\leq 0.03$ & $\leq 0.08$ & $\leq 0.15$ & $\leq 0.5$ \\
\cline { 2 - 7 } & $\mathrm{mg} / \mathrm{MJ}$ & $\leq 0.04$ & $\leq 0.06$ & $\leq 0.16$ & $\leq 0.3$ & $\leq 1.0$ \\
\hline
\end{tabular}

Adapted from: (Szpadt, 2012).

It should be noted that exemplary studies (Czop, 2018) on a mixture of dried and granulated sludge and polyolefins separated from the municipal waste stream showed the following qualitative characteristics:

- net calorific value: $19.56[\mathrm{MJ} / \mathrm{kg}]$,

- mercury content: $0.02[\mathrm{mg} / \mathrm{MJ}]$,

- chlorine content: $0.11 \%$.

The presented elementary composition of fuels confirms the possibility of classifying such fuels from waste to high class solid secondary fuels.

\subsection{Legal analysis and development directions}

The Act on Waste of April 21, 2001 (Journal of Laws 2010.185.1243), is considered to be the basic act regulating waste management, and thus also municipal sewage sludge, accompanied by a number of regulations, including, among others:

- Regulation of the Minister of Environment of February 6, 2015, on municipal sewage sludge (Journal of Laws of 2015, item 257);

- Regulation of the Minister of Climate of January 2, 2020, on waste catalogue (Journal of Laws of 2020, item 10);

- Regulation of the Minister of Economy of July 16, 2015, on allowing waste to be placed at landfills (Journal of Laws of 2015, item 1277).

In the case of thermal transformation of municipal sewage sludge, the Polish legislation regulates this issue, among others, in the following legal acts: in the provisions of the Act of April 27, 2001, Environmental Protection Law (Journal of Laws of 2018, item 799, as amended) and the above-mentioned Act on Waste, including executive regulations, in particular: 
- Regulation of the Minister of Environment of 2014 on the Requirements concerning measurement of emission volume and the amount of water drawn (Journal of Laws of 2014, item 1542);

- Regulation of the Minister of Environment of November 4, 2014, on emission standards for certain types of installations, sources of combustion of fuels and equipment for incineration or co-incineration of waste (Journal of Laws of 2014, item 1546);

- Regulation of the Minister of Development of January 21, 2016, on the requirements for conducting the process of thermal transformation of waste and the methods of handling waste resulting from this process (Journal of Laws of 2016, item 108).

In this case, it is worth noting the fact that it is possible to classify energy from sewage sludge combustion as energy from a renewable energy source. Of course, this requires a number of conditions to be met, but the basis for such a possibility are the provisions of the Renewable Energy Sources Act of February 20, 2015 (Journal of Laws of 2018, item 1269, as amended). The abovementioned act defines biomass as a biodegradable fraction of industrial and municipal waste, of plant or animal origin, including from waste treatment facilities, as well as water and sewage treatment plants, in particular sewage sludge, in accordance with waste regulations.

In addition, the provisions of the above-mentioned Act give the possibility to also include in the support system for the use of energy from renewable sources the technologies of biogas combustion produced, among others, in sewage treatment plants as a result of methane fermentation. This means that, in practice, it is possible to classify appropriate part of electric power (and/or heat) produced by the co-incineration of alternative fuels (e.g. sludge-based) as renewable energy sources.

Apart from the legal regulations, it is also worth to outline development directions related to waste management, including sewage sludge, which, on the basis of detailed analyses, forecast changes and specify guidelines aimed at proper adaptation of the system.

The Strategy for handling municipal sewage sludge for 2019-2022, developed by the Ministry of Environment in 2018, based on a detailed diagnosis of the sewage sludge management system in Poland, identifies directions to ensure proper treatment of municipal sewage sludge. These directions include: increasing the amount of municipal sewage sludge treated before its release into the environment and increasing the amount of municipal sewage sludge treated thermally.

Also within the framework of the National Intelligent Specializations established in Poland (which indicate preferential areas of support for R\&D works, serving the transformation of the Polish economy into a circular economy model), an area called "IV. Waste and sewage" was recognized, where the following topics were specified: (a) use, recovery and optimization of energy consumption in water and sewage management, (b) technologies using sewage and sludge as substrates for energy generation. 


\subsection{Technologies related to the energy use of sewage sludge}

The most common methods of sewage sludge management and disposal in Poland include: agricultural / natural use, land and landfill reclamation, creation of sewage treatment plant sites and sludge storage on the area of the plant, production of compost, storage on municipal waste landfills, thermal utilization.

The share of applied solutions in sewage sludge management was determined by the requirements of the European Union, which directly translated into the objectives of municipal sewage sludge management in Poland:

1) no more storage of municipal sewage sludge,

2) increasing the amount of municipal sewage sludge treated before its release into the environment, as well as thermally treated sewage sludge,

3) pursuing the maximization of the use of biogenic substances contained in the sludge while meeting all sanitary, chemical and environmental safety requirements (Ministerstwo Środowiska, 2018).

In the context of thermal processing, there has been a dynamic development in recent years. In the area of scientific research, interest in the use of sludge as a substrate for the production of alternative fuels has increased, as well as in the search for technological solutions to increase the efficiency of its processing.

Currently, among the most common solutions for thermal transformation of sewage sludge, we can highlight numerous technological variants related to its incineration, co-incineration, as well as treatment with alternative processes (Fig. 2).

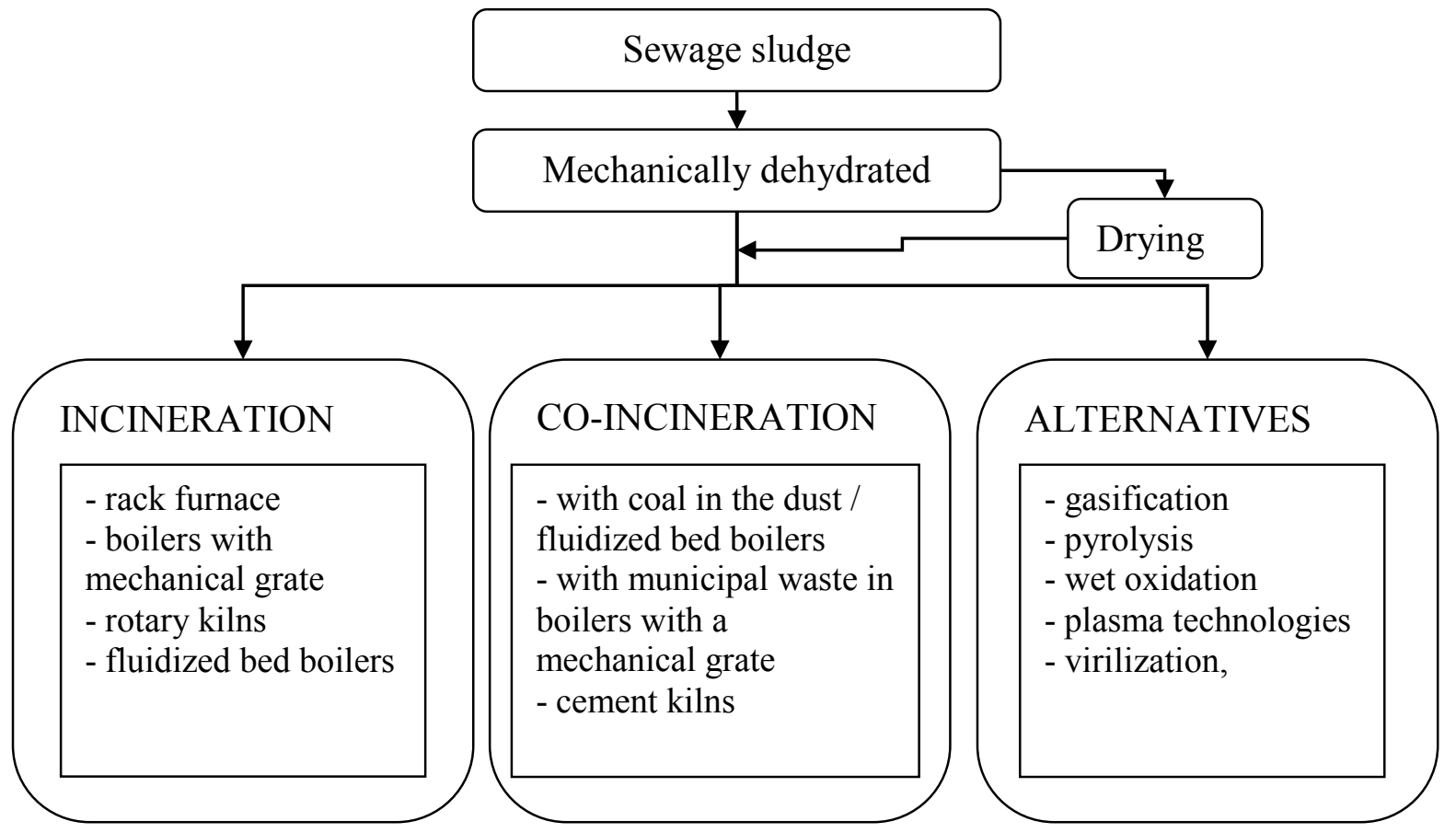

Figure 2. Thermal methods of sewage sludge conversion - technological variants. Adapted from (Bień et al., 2011). 
The literature of the subject (Fericelli, 2011; Tarpani et al., 2020; Vatachi, 2019) shows that the consideration of thermal applications as a waste management solution, including sewage sludge management, is currently of increasing importance. Nowadays, in many European countries, sewage sludge is treated by thermal transformation - incineration - as shown by the statistics presented in the table (Bień et al., 2011).

Table 3.

Sewage sludge production and incineration from urban wastewater (in dry substance (thousand tons))

\begin{tabular}{|c|c|c|c|c|c|c|c|c|c|}
\hline TIME & \multicolumn{3}{|c|}{2015} & \multicolumn{3}{|c|}{2016} & \multicolumn{3}{|c|}{2017} \\
\hline & \multirow[t]{2}{*}{$\begin{array}{c}\text { Sludge } \\
\text { production } \\
\text { - total } \\
\end{array}$} & \multicolumn{2}{|c|}{$\begin{array}{l}\text { Sludge disposal } \\
\text { - incineration }\end{array}$} & \multirow[t]{2}{*}{$\begin{array}{c}\text { Sludge } \\
\text { production } \\
\text { - total } \\
\end{array}$} & \multicolumn{2}{|c|}{$\begin{array}{l}\text { Sludge disposal } \\
\text { - incineration }\end{array}$} & \multirow[t]{2}{*}{$\begin{array}{c}\text { Sludge } \\
\text { production } \\
\text { - total } \\
\end{array}$} & \multicolumn{2}{|c|}{$\begin{array}{c}\text { Sludge } \\
\text { disposal } \\
\text { - incineration }\end{array}$} \\
\hline $\begin{array}{l}\text { GEO } \\
\text { (Labels) }\end{array}$ & & & & & & & & & \\
\hline $\begin{array}{l}\text { Czech } \\
\text { Republic }\end{array}$ & 210.24 & 14.24 & $7 \%$ & 206.71 & 18.91 & $9 \%$ & 223.27 & 24.99 & $11 \%$ \\
\hline Germany & $1,803.087$ & $1,148.679$ & $64 \%$ & $1,794.443$ & $1,142.893$ & $64 \%$ & $:$ & $\cdot$ & \\
\hline Greece & 119.768 & 38.36 & $32 \%$ & 119.768 & 38.36 & $32 \%$ & $:$ & $:$ & \\
\hline France & 1,238 & 138 & $11 \%$ & 1,006 & 136 & $14 \%$ & 1,174 & 149 & $13 \%$ \\
\hline Hungary & 172.01 & 23.02 & $13 \%$ & 215.08 & 60.53 & $28 \%$ & 264.71 & 64.19 & $24 \%$ \\
\hline Malta & 8.44 & 0 & $0 \%$ & 10.77 & 0 & $0 \%$ & 10.3 & 0 & $0 \%$ \\
\hline Netherlands & 354.6 & 322.414 & $91 \%$ & 347.6 & 319.846 & $92 \%$ & $:$ & $:$ & \\
\hline Poland & 568 & 79.3 & $14 \%$ & 568.329 & 101.144 & $18 \%$ & 584.454 & 106.158 & $18 \%$ \\
\hline Romania & 210.45 & 0.5 & $0 \%$ & 240.41 & 0.38 & $0 \%$ & 283.34 & 0.02 & $0 \%$ \\
\hline Slovenia & 29.1 & 15.1 & $52 \%$ & 32.8 & 15.9 & $48 \%$ & 36.7 & 12.4 & $34 \%$ \\
\hline Slovakia & 56.24 & 16.91 & $30 \%$ & 53.05 & 11.04 & $21 \%$ & 54.52 & 12.24 & $22 \%$ \\
\hline
\end{tabular}

Adapted from: Eurostat.

Selected countries, for which statistics were available, are presented. It can be noted, that the largest share of sludge incineration is in the Netherlands, Germany and Slovenia. In Germany, the share of co-incineration of sewage sludge has started to increase rapidly over the last century, which is currently higher than that of self-incineration. In the case of Poland, co-incineration of mechanically dehydrated or dried sewage sludge is carried out in particular in cement plants and, in the near future, after meeting certain requirements related to EU emission standards, it may be carried out in other facilities, such as heat and power plants or municipal waste incinerators (Pająk, Niesler, 2014).

According to data from the Strategy (Ministerstwo Środowiska, 2018), currently there are 11 municipal sewage sludge mono-incineration plants in Poland, with a total capacity of 160.3 thousand Mg DM/year. Among them we can identify:

- Sewage Sludge Thermal Treatment Plant, located on the site of the "FORDON" sewage treatment plant in Bydgoszcz, being an integral part of it. The capacity of the installation is 21-30 tons of dry matter per day. The dried sludge with approximately $33 \%$ dry matter content is burned in a fluidized bed furnace (Miejskie Wodociągi i Kanalizacja w Bydgoszczy, 2020); 
- Sewage Sludge Thermal Treatment Plant in Warsaw (located in the "Czajka" area), based on the technology of fluidized bed incineration. It is the only installation in Poland with combined heat and power generation (in a steam turbine);

- Sludge Thermal Disposal Station in Cracow, located on the site of Płaszów Wastewater Treatment Plant, with an average capacity of 64 tons of dry matter per day (Wodociągi Miasta Krakowa, 2020). The installation uses a Haarslev membrane disk dryer with a capacity of $12100 \mathrm{~kg} / \mathrm{h}$ of wet sludge (22\% DM), which corresponds to $4,714 \mathrm{~kg}$ of evaporated water per hour. The dryer is supplied with heat in the form of hot steam, which is recovered from the sludge incineration process. The dried sludge is then subjected to a Pyrofluid ${ }^{\mathrm{TM}}$ combustion process, which is carried out in a fluidized bed furnace. The target capacity of the incineration plant is $64 \mathrm{t}$ of DM/day (Veolia, 2020).

Practice shows that sewage sludge incineration plants are rational in large treatment plants associated with large agglomerations, as is the case of the mentioned facilities in Bydgoszcz, Warsaw and Cracow. However, such incinerators also operate in Łódź, Gdańsk, Szczecin and Kielce. An example of the smallest town where sewage sludge from a treatment plant is thermally transformed is Łomża, where the Sewage Sludge Thermal Mineralization Plant is located. The technology is based on a grate furnace and an integrated exhaust gas treatment system.

The total capacity of the existing sludge thermal transformation installations in Poland is $160,000 \mathrm{Mg} \mathrm{DM} /$ year (Bień et al., 2014). It is also worth noting the slow increase in interest in the share of alternative fuels used in the clinker burning process. According to data from the Polish Cement Association, in 2016, the use of alternative fuels amounted to almost $70 \%$ (the rest was coal consumption) (Polish Cement Association, 2019). In the general structure of used alternative fuels, sludge alone represented less than $1 \%$, while $\mathrm{RDF}=86 \%$. In order to become a desired fuel for cement plants, sewage sludge must, first of all, be dried until the dry matter content reaches at least $90 \%$ and contain as little dust as possible. Therefore, the sludge dryer should be selected so that it meets all requirements. Another solution is to transfer the sewage sludge to alternative fuel ( $\mathrm{RDF}$ - refuse-derived fuel) production facilities, where it can be mixed with structural material in the form of a high calorific fraction (combustible waste). According to the literature (Bożym, 2013), an example of an alternative fuel based on sewage sludge is its mixture with waste coal sludge, which creates granules. Another example is PBS fuel, consisting of sewage sludge (53-62\%), coal sludge (35-37\%) and burnt lime (3-10\%) in cement kilns (Troniewski, Wzorek, 2004).

As regards the use of thermal methods to treat sludge, it is essential that the sludge should be dried beforehand, which is a basic condition for its possible disposal, including as fuel.

The sludge drying or dewatering process is carried out in separate or combined drying companies. Used types of dryers include: disc dryer; drum dryer; fluidized bed dryer; belt dryer; solar dryer; as well as combination of different types. The drying process can basically be 
divided into two groups: partial drying, up to about $60-80 \%$ of dry matter content; total drying, up to about $80-90 \%$ (EC, 2006).

Drying sludge in addition to increasing its calorific value allows for a significant reduction in volume and weight and provides opportunities for temporary storage and transport. (Chalamoński, Szymczak, 2017; Kapiszewski, 2016).

Another important aspect in the case of sewage sludge is the possibility to granulate or briquette it. In literature (Kosturkiewicz, Janewicz, 2015), studies were carried out on an attempt of briquetting municipal sewage sludge with burnt lime (as sorbent) and fine-grained hard coal. In other studies, briquettes were formed from a mixture of sewage sludge and waste burnt lime, creating a product characterized by good fuel properties (about $12 \mathrm{MJ} / \mathrm{kg}$ ) at $10 \%$ moisture content (Kosturkiewicz, Magdziarz, Wilk, 2011). This confirms the relevance of exploring solutions to convert sewage sludge into alternative fuel by mixing it with other, specially selected components, producing fuels in granular form, with energy properties allowing their use in co-incineration with coal, in particular in the process of burning cement clinker.

The dried sewage sludge can be used for co-incineration, as a mixture with waste wood, rapeseed and rye straw, pine bark and coal in different volume and mass proportions. The calorific value of the dried sewage sludge is about $14 \mathrm{MJ} / \mathrm{kg}$. The dried sewage sludge is free of heavy metals, but has a significant amount of ash reaching up to $35 \%$ of its weight (Chalamoński, Szymczak, 2017).

\section{Conclusions}

Excess sewage sludge means that treatment plants need to look for new solutions to manage and use it properly. The requirements of the European Union in terms of share of renewable energy in the total energy production determine the need to take actions related to more effective use of the energy potential of biomass and sewage sludge.

Sewage sludge, which cannot be used for agricultural purposes due to its inadequate chemical composition, is thermally treated in most of the large urban agglomerations.

The problem of rational management of municipal sewage sludge has become a serious economic, ecological, technical and social problem in Poland.

The adopted legal documents and strategies clearly indicate the energy use of sludge as one of the directions to ensure proper treatment of municipal sewage sludge.

As regards environmental issues, the incineration and co-incineration of sewage sludge in cement kilns is a pro-environmental solution, which allows, among others:

- for legal regulations to treat sewage sludge as a $\mathrm{CO}_{2}$-neutral energy source,

- to increase the possibility of obtaining additional renewable energy sources, 
- to reduce the consumption of fossil fuels,

- the possibility of managing large amounts of sewage sludge - high process efficiency,

- the possible recovery of phosphorus from ashes (possibly only in mono-incineration plants).

However, it should be noted that, in the context of physico-chemical properties, sludge is classified as a difficult alternative fuel, mainly due to the following factors:

- Due to hydration, the use of sewage sludge as an alternative fuel is difficult, so it has to be dried or mixed with waste with high dry matter content (high costs of sludge drying installations and significant heat consumption).

- In terms of chemical composition of sewage sludge, the parameters limiting its use are mercury, chlorine and $\mathrm{P}_{2} \mathrm{O}_{5}$ content (this is particularly important in cement plants).

- Due to the variability of the sludge composition, it is necessary to analyze it regularly, in order to obtain a complete picture of possible changes.

- The use of municipal sewage sludge for incineration in the professional power industry requires that energy installations meet the requirements for the thermal conversion of waste.

- Sludge in the form of granules is the preferred alternative fuel (preparation costs).

- Economic issues - the cement plant charges the sludge producer, treatment plant, a fee for each ton of delivered dewatered sludge.

The implementation of a sludge mono-incineration plant is considered a practical and rational solution. This is important because of the possibility to recover energy from the sludge incineration process and use it for sludge drying. Such installations involve high investment expenditure and their practical application is particularly visible in large agglomerations (reduces to a minimum the need to export the sludge to other installations - burdensome for local residents).

However, the recent trend in the expansion of sewage treatment plants to include sludge drying facilities allows for a new look at the energy use of sludge and a significant expansion of potential customers of this fuel. In this context, the size of the treatment plant, which determines the energy efficiency of the solution, is also important.

Taking into account the above solutions, the energetic use of sludge is still an ecologically important topic, but it is significantly limited by economic issues. In this respect, a comprehensive approach is required, taking into account the whole sludge management system at a local level. The possibility to diversify sewage sludge management at the level of an individual plant provides greater opportunities to cope with the increasing amount of generated sludge, as well as with legal and market requirements related to its management. In order for the implemented solutions to be justified, it is crucial to increase the measurable benefits for plants that generate sludge, and not only for plants treating them thermally. 


\section{References}

1. Bauman-Kaszubska, H., Sikorski, M. (2011). The quality and quantity characteristic of sewage sludge coming from small sewage treatment plants on the area of plock county. Inżynieria Ekologiczna, $n r$ 25, pp. 20-29

2. Bień, J. (2011). Zagospodarowanie komunalnych osadów ściekowych metodami termicznymi. Inżynieria i Ochrona Środowiska, t. 15, $n r$ 4, pp. 439-449. Retrieved from https://ios.is.pcz.pl/images/ios_repo/2012/zeszyt4/9_2012_Bien.pdf.

3. Bień, J.D., Szymanek, A., Bień, B. (2011). Alternatywne dla spalania metody termicznej utylizacji komunalnych osadów ściekowych. Wydawnictwo Politechniki Częstochowskiej, pp. 1-86. Retrieved from http://ekordo.pl/wp-content/uploads/2019/05/skrypt.pdf.

4. Bień J. et al. (2014). Ekspertyza, która będzie stanowić materiat bazowy do opracowania strategii postepowania z komunalnymi osadami ściekowymi na lata 2014-2020. Częstochowa: Politechnika Częstochowska, Wydział Inżynierii Środowiska i Biotechnologii Instytut Inżynierii Środowiska.

5. Bożym, M. (2013). Wymagania jakościowe stawiane osadom ściekowym spalanym w krajowych cementowniach. Chemik, 67, 10, pp. 1019-1024.

6. Chalamoński, M., Szymczak, M. (2017). Wysuszony osad ściekowy jako paliwo alternatywne. Journal of Civil Engineering, Environment and Architecture, t. XXXIV, z. 64, (1/17). Retrieved from http://doi.prz.edu.pl/pl/pdf/biis/746.

7. Czop, M. (2018). Energetyczna przydatność oraz uciążliwość dla środowiska wybranych paliw z odpadów. Przemyst Chemiczny, vol. 1(9), pp. 50-52.

8. EC (2006). Integrated Pollution Prevention and Control Reference Document on Best Available Techniques for Waste Incineration. European Commission, August 2006. Retrieved from https://ippc.mos.gov.pl/ippc/custom/spalanie\%20odpad\%C3\%B3w.pdf.

9. Fericelli, P.D. (2011). Comparison of Sludge Treatment by Gasification vs. Incineration. 9th Latin American and Caribbean Conference for Engineering and Technology. WE1-10. Retrieved from http://energy.cleartheair.org.hk/wp-content/uploads/2013/05/PM022_ Fericelli_SP.pdf.

10. Geoland. Available online http://geoland.pl/dodatek/jakosc-normalizacja-certyfikacja13/osady-sciekowe-zrodlem-energii-alternatywnej-2/, 28.04.2020.

11. Kapiszewski, J. (2016). Nowe paliwo polskiego naukowca: Osady z oczyszczania ścieków. Retrieved from https://serwisy.gazetaprawna.pl/msp/artykuly/930004,paliwo-polskiegonaukowca-osady-z-oczyszczania-sciekow.html.

12. Kosturkiewicz, B. Janewicz, A. (2015). Brykietowanie osadów ściekowych z wapnem palonym i węglem kamiennym w prasach walcowych. Przemyst Chemiczny, T. 94, nr 9, pp. 1524-1526. Retrieved from http://yadda.icm.edu.pl/baztech/element/bwmetal element. baztech-e8726e28-d507-4b9b-a1b6-f636c9f7073c. 
13. Kosturkiewicz, B., Magdziarz, A., Wilk, M. (2011). Osady ściekowe jako paliwo odnawialne. Rynek Energii, październik. Retrieved from https://www.cire.pl/pliki/2/ sciekowe_jako_odnawialne.pdf.

14. KPGO (2016). Krajowy plan gospodarki odpadami 2022. Warszawa. Retrieved from https://bip.mos.gov.pl/fileadmin/user_upload/bip/strategie_plany_programy/DGO/Krajow y_plan_gospodarki_odpadami_2022___M.P._poz._784_.pdf.

15. Kuklis, I., Mazurek, I., Jagustyn, B. (2014) Parametry klasyfikacyjne stałych paliw wtórnych wytwarzanych z komunalnych osadów ściekowych. Ochrona Środowiska, vol. 36, $n r$ 4, pp. 51-56.

16. Magdziarz, A., Wilk, M., Kosturkiewicz, B. (2011). Investigation of sewage sludge preparation for combustion process. Chemical and Process Engineering, 32(4), pp. 299309. Retrieved from http://journals.pan.pl/Content/84630/PDF/06-paper-Magdziarz.pdf.

17. Miejskie Wodociągi i Kanalizacja w Bydgoszczy (2020). Available online https://www.mwik.bydgoszcz.pl/index.php/instalacja-termicznego-pzeksztalcaniaosadow, 28.04.2020.

18. Ministerstwo Środowiska (2018). Strategia postępowania z komunalnymi osadami ściekowymi na lata 2019-2022. Warszawa.

19. Ostrojski, A. (2015). Biomasa. Inżynieria Morska i Geotechnika, nr 1/2015, pp. 3-7.

20. Pająk, T. (2013). Thermal treatment as sustainable sewage sludge management. Environment Protection Engineering, vol. 39, no. 2. Retrieved from http://epe.pwr.wroc.pl/ 2013/2-2013/Pajak_2-2013.pdf.

21. Pająk, T., Niesler, M. (2014). Successes and failures of thermal treatment of communal sewage sludge in Poland. Archives of Journal of Waste Management and Environmental Protection, vol. 16, $n r$ 3, pp. 79-86.

22. Polish Cement Association (2019). Retrieved from https://www.polskicement.pl/wpcontent/uploads/2019/10/Biuletyn-SPC-2019-www.pdf.

23. Sorek, A., Borecki, M., Ostrowska-Popielska, P. (2012). Selected plastic waste as a source of alternative fuels in the metallurgical industry. Prace Instytutu Metalurgii Żelaza, r. 64, nr 4, pp. 47-57.

24. Szpadt, R. (2012). Paliwa z odpadów. Standardy. Politechnika Wrocławska oraz Agencja Rozwoju Aglomeracji Wrocławskiej. Retrieved from https://sdr.gdos.gov.pl/Documents/ GO/Spotkanie\%2010.01.2012/RSZPADT--Paliwa-z-odpadow-Standardy--Warszawa10012012.pdf.

25. Tarpani, R., Alfonsín, C., Hospido, A., and Azapagic, A. (2020). Life cycle environmental impacts of sewage sludge treatment methods for resource recovery considering ecotoxicity of heavy metals and pharmaceutical and personal care products. Journal of Environmental Management, vol. 260. Retrieved from https://www.sciencedirect.com/science/article/pii/ S0301479719313611. 
26. Troniewski, L., Wzorek, M. (2004). Osady ściekowe jako paliwa alternatywne dla przemystu cementowego. Mat. Konf. Energia i środowisko w technologiach materiałów budowlanych, pp. 381-388.

27. Vatachi, N. (2019). Wastewater sludge to energy production. A review. The $22^{\text {nd }}$ National Conference on Thermodynamics with International Participation. IOP Conf. Series: Materials Science and Engineering vol. 595. Retrieved from https://iopscience.iop.org/ article/10.1088/1757-899X/595/1/012053/pdf.

28. Veolia (2020). Stacja Termicznej Utylizacji Osadów w Krakowie-Płaszowie. Available online http://www.veoliawatertechnologies.pl/media/case_studies_Veolia/STUO Krakow.htm, 28.04.2020.

29. Wodociągi Miasta Krakowa (2020). Available online https://wodociagi.krakow.pl/ o-firmie/nasze-zaklady/oczyszczalnia-plaszow/stacja-termicznej-utylizacji-osadow.html, 28.04.2020. 